\title{
Case Report Leucocytozoonosis pada Kalkun (Meleagris gallopavo)
}

\author{
Case Report Leucocytozoonosis in Turkey (Meleagris gallopavo) \\ Yesica, R1*, Wisesa, I.B.G.R1, Inayatillah, A2, Pramayanti, A.M², Maurenda, A.D2, \\ Abrianto, B2 , Al-Kindy, D.W2, Octaviani, D.I.D.A2 \\ ${ }^{1}$ Laboratory of Veterinary Medicine, Faculty of Veterinary Medicine, Universitas \\ Brawijaya \\ ${ }^{2}$ Doctor of Veterinary Medicine Program, Faculty of Veterinary Medicine, Universitas \\ Brawijaya \\ *email: rezayesica@ub.ac.id
}

\begin{abstract}
ABSTRAK
Leucocytozoon adalah parasite genus protozoa yang termasuk dalam filum Apicomplexa yang menginfeksi species unggas. Leucocytozoonosis merupakan salah satu penyakit yang masih sering muncul pada ayam. Angka kematian pada ayam pedaging bisa mencapai $40 \%$. Meskipun kasus penyakit ini lebih banyak ditemukan di peternakan ayam pedaging, bukan berarti ayam petelur dan kalkun dapat lolos dari infeksi parasit ini. Kasus Leucocytozoonosis pada ayam petelur dan kalkun jarang terjadi, namun jika Leucocytozoonosis menyerang, angka kematian bisa mencapai 30\%. Hal tersebut juga menyebabkan peningkatan nilai FCR (Feed Conversion Ratio) dan penurunan produksi telur. Dalam penelitian ini diambil sampel darah dari kalkun betina berumur 2 tahun. Hasil pemeriksaan menunjukkan bahwa kalkun terinfeksi protozoa Leucocytozoon sp. Pengobatan pada unggas dapat dilakukan dengan pemberian chloroquine, trimethoprim, sulphaquinoxaline, dan primaquine serta menjaga kebersihan kandang.
\end{abstract}

Kata kunci: Leucocytozoon sp., Protozoa, Kalkun

\begin{abstract}
Leucocytozoon is a genus of parasitic protozoa belonging to the phylum Apicomplexa that infect numerous species of avian hosts. Leucocytozoonosis is one of the diseases that still often appear in chicken. The mortality rate in broilers can reach $40 \%$. Although cases of this disease are more commonly found in broiler farms, it doesn't mean that laying hens and turkeys can not infected. Cases of Leucocytozoonosis in laying hens and turkeys are rare, but if Leucocytozoonosis attacks, the death rate can reach $30 \%$. It also causes an increase in the value of the FCR (Feed Conversion Ratio) and decrease egg production. In this study we collected the blood sample from 2 years old female turkey. The examination result showed that the protozoa Leucocytozoon $s p$. In Indonesia turkey which infected by Leucocytozoon sp. can be treated with chloroquine, trimethoprim, sulphaquinoxaline, and primaquine also maintaining the sanitary of the cage.
\end{abstract}

(C)2020. Yesica et al. Open access under CC BY - SA license, doi: $10.20473 / \mathrm{mkh} . v 31 i 1.2020 .45-51$

Received: 28-11-2019, Accepted: 18-01-2020, Published online: 29-01-2020

Available at https:/ /e-journal.unair.ac.id/MKH/index 


\section{INTRODUCTION}

Indonesia is a developing country with a fairly low level of awareness of environmental cleanliness. An unclean environment will cause many diseases, one of them parasitic. Parasitic diseases are commonly found in animals and are often transmitted to humans (zoonoses). Some business sectors, for example livestock, often suffer losses due to parasitic diseases that attack their livestock. Parasitic diseases are also among the most cases in several animal clinics and conservation parks in Indonesia (Tjitra, 2008).

According to Ternaningsih (2007) the tropics have several quite dangerous diseases caused by bacteria, viruses, protozoa and also helminth. Disease in poultry, especially chickens, one of which can be caused by parasites. Protozoa can cause death in poultry farms. Plasmodium, Haemoproteus and Leucocytozoon are protozoa that live as parasites in red blood cells, which cause poultry malaria (avian malaria) (Tabbu, 2002).

The tropics are suitable habitat for malaria vectors, such as the Culex, Anopheles, Culiceta, Mansonia, and Aedes mosquitoes. In addition to the geographical factors of Indonesia which has a tropical climate there is also environmental issues in the form of global warming. Global warming causes climate change and temperature which have an impact on environmental damage and the emergence of various diseases such as dengue fever and malaria (Tsai and Liu, 2005).

Leucocytozoonosis is one of the diseases that still often appear in chicken farms in Indonesia. Losses caused by broilers include increasing the number of chicken and the decline in the quality of chicken carcasses. The mortality rate in broilers can reach $40 \%$. Although cases of this disease are more commonly found in broiler farms, it 
doesn't mean that laying hens and turkeys can not infected. Cases of Leucocytozoonosis in laying hens and turkeys are rare, but if Leucocytozoonosis attacks, the death rate can reach $30 \%$. It also causes an increase in the value of the FCR (Feed Conversion Ratio) and decrease egg production.

The number of vectors carrying sporozoite forms in an area greatly influences the prevalence of disease in the area (Ririen, 2004). Prevalence of Leucocytozoon sp. in free-range chicken in Bali 53.58\% (Apsari dan Arta, 2010), and the prevalence of Leucocytozoon sp. in Bali ducks 23.75\% (Apsari and Arta, 2004). Research on broilers in Nanggroe Aceh Darussalam found the prevalence of Leucocytozoon sp. by $30 \%$ while in ducks found $24 \%$ (Hanafiah et al., 2007).

Seeing the impact of poultry malaria that can threaten livestock, it is necessary to conduct research on the presence of parasites, by observing and documenting visually using a microscope on blood smear preparations. This study wiil be give information about the presence of Leucocytozoon sp. which lives as parasites in red blood cells in poultry, especially turkeys.

\section{MATERIALS AND METHOD}

\section{Clinical Symptoms and Examination}

A two years female turkey was reported anorexia, the hair looks dull and the egg size gets smaller. Turkey looks thinner due to decreased appetite. Besides other clinical symptoms are dull hair, wattle look pale and decreased egg production. Suspected of being infected with blood protozoa, a parasitological examination can be done in the form of blood smear with Giemsa $10 \%$ preparations or touch preparations of infected organs.

\section{Laboratory Examination}

Blood sampling is obtained from a turkey whose blood is taken through the 
brachial vein. The turkey blood sample is then put into a tube containing EDTA and labeled. Next is make a thin blood smear with Giemsa 10\% then observed under a light microscope with a magnification of 1000 x. Observations were made to identify blood protozoa in the preparations.

\section{RESULTS}

Based on clinical symptoms, physical examination, and laboratory examination, turkey was diagnosed Leucocytozoon sp. with fausta prognosis.

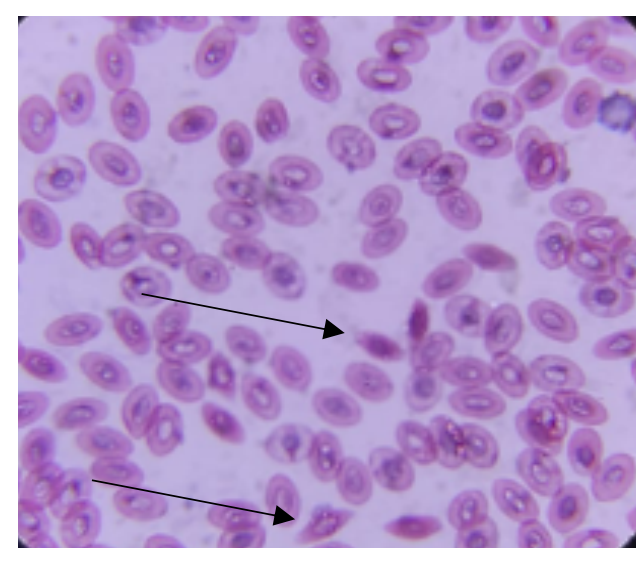

Figure 1.1 Turkey blood Leucocytozoon sp. samples with Giemsa staining (On arrow $\rightarrow$, 100x10 magnification)

\section{DISCUSSION}

Leucocytozoon is the largest haemoprotozoa encountered in birds. Leucocytozoon is occasionally pathogenic in young raptors, turkey and waterfowl in which be caused haemolytics anemia and haemoglobinuria. The disease is known colloquially as turkey malaria, duck malaria or gnat fever. Clinical signs of Leucocytozoon of Plasmodium and have a life cycle similar to Haemoproteus. Turkey with chronic infection of Leucocytozoon have weak immune system 
and reduce reproduction. Severe infection produce emaciation, dehydration and convulsion that lead to death. Internally the liver and spleen of hosts are enlarged, the heart muscle id pale and the lungs are congested (Soulsby, 1982).

Macrogametocytes and microgametocytes of Leucocytozoon can be differentiated on similar characteristics from those of Plasmodium and Haemoproteus, they lack the presence of melanin pigment seen in the other two genera, although small reddish granules are often present (Tampubolon, 1992). Leucocytozoon gametocyte does not contain refractile pigment and changes the shape of the host cell. An elongate form and round form were observed in birds. The appearance of both round and elongated gametocytes evidenced that the Leucocytozoon is a pathogenic strain. In the present study we found only the elongated form of the blood parasite in chickens (Soulsby, 1982). Though both elongated and round forms were observed but there were more elongated forms. In the present study, we obtained an unidentified species of Leucocytozoon from blood of investigated chickens.16 chickens were found infected by Leucocytozoon sp. The gametocytes were found in fusiform host cells. The measurements of the macrogametocyte of Leucocytozoon sp. from blood smears of chickens were $10.4 \pm 0.3 \mu \mathrm{M} \times 4.9 \pm 0.28 \mu \mathrm{M}$. Invasion intensity ranged from 2 to 4 per 100 microscopic fields. The size of parasite nucleus was $3.3 \pm 0.13 \mu \mathrm{M} \times 2.4 \pm 0.21 \mu \mathrm{M}$.

Leucocytozoon smithi in turkey is one of haemoprotozoa that have a high mortality it can be fatal in poultry. Infection of Leucocytozoon species undergo a complex like-malaria life cycle. Gametocytes in the blood of an avian host are acquired by a female black fly. The parasite then undergoes both sexual and asexual development over period 3 - 4 day in the fly. Incubated period is about 14 - 21 days after 
turkeys are infected by black flies. During the subsequent blood meal the fly tramsmits the parasite as sporozoites to another bird which serves as a host for asexual development and gametocyte production.

Clopidol (coyden) will eliminate the mature gametocytes from blood, however this will not help treat or prevent the symptoms or lesion. In Indonesia turkey which infected by Leucocytozoon can be treated with chloroquine, trimethoprim, sulphaquinoxaline, and primaquine.

\section{CONCLUSION}

Blood protozoa are obtained from turkeys aged 2 years with clinical symptoms of anorexia, the hair looks dull and the egg size gets smaller. In laboratory examination with blood smear method it was found the presence of Leucocytozoon sp. Turkey that affected by Leucocytozoon sp. can be treated by Chloroquine, trimethoprim, sulphaquinoxaline, and primaquine.

\section{REFERENCES}

Apsari I.A.P. and I.M.S. Arta. 2004. Blood

Parasites of Bali Ducks Sampled from Traditional Farming System in Bali. Jurnal Veteriner 5(4): 133-138. Laboratory of Veterinary Parasitology Faculty of Veterinary Medicine, Udayana University, Denpasar.

Apsari, I.A.P dan I.M.S. Arta. 2010. Gambaran Darah Merah Ayam Buras yang Terinfeksi Leucocytozoon. Jurnal Veteriner Juni 2010 Vol. 11 No. 2: 114-118. Laboratorium Parasitologi Veteriner Fakultas Kedokteran Hewan Universitas Udayana, Denpasar.

Hanafiah, M., R. Sulaiman dan N. Latif. 2007. Pemeriksaan Leucocytozoon pada Broiler dan Itik menggunakan Metode Gerusan dan Hapusan Darah. Jurnal Veteriner 8(1) Maret: 9-12

Ririen, N. W. 2004. Potensi Lalat Culicoides terhadap Prevalensi Leucocytozoonosis 
pada Ayam. Journal Biosains International Workshop, Asker, Near Pascasarjana 6(1): 5-9

Soulsby, E.J.L. 1982. Helmints, Arthropods, and Protozoa of Domesticated Animals 7th edition. Bailliere Tindal, London.

Tabbu, C.R. 2002. Penyakit Ayam dan Penaggulangannya - vol. 2. Kanisius, Yogyakarta.

Tampubolon, M. 1992. Petunjuk Laboratorium Protozoologi. IPB Press, Bogor.

Ternaningsih, E. 2007. Jangan Abaikan Penyakit Tropis. Suara Pembaharuan 5 Febuari 2007.

Tjitra. 2008. Pengobatan Malaria dengan Kombinasi Artemisin. Puslitbang Pemberantasan Penyakit Badan Litbangkes, Jakarta.

Tsai, H. T and Liu, T. M. 2005. Effects of Global Climate Change on Disease Epidemics and Social Instability around the World.
Oslo. 